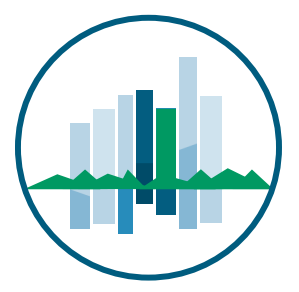

True Smart and Green City?

8th Conference of the

International Forum on Urbanism
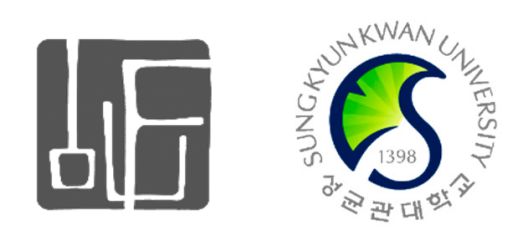

Conference Proceedings Paper

\title{
Specific Barriers to Massive Scale Energetic Refurbishment for Sample Markets in Europe
}

\author{
Clara Camarasa ${ }^{1, *}$, Claudio Naegeli ${ }^{1}$, Corinna Salzer ${ }^{1}$, Saurabh Saraf ${ }^{2}$ and York Ostermeyer ${ }^{1}$ \\ 1 Chalmers Tekniska Högskola/ SE-412 96, Gothenburg, Sweden \\ 2 Biopolus / Záhony u. 7. 1031 Budapest, Hungary \\ * Author to whom correspondence should be addressed; Tel.: +46-840-47-87; \\ E-Mail: camarasa@chalmers.se.
}

\begin{abstract}
International bodies such as the Intergovernmental Panel on Climate Change or the United Nations agree in seeing the built environment as one of the key sectors to mitigate emissions. Cost abatement curves as generated by McKinsey list a number of technologies in the building sector, which are already cost effective and are together potentially allowing for carbon mitigations of 2,0-3,0 Gtons of $\mathrm{CO}_{2}$ eq per annum. Despite being economically attractive as well as desirable from a climate change mitigation viewpoint, almost none of these technologies are massively upscaling. The European Union requires the individual member countries to implement measures to speed up energy efficiency in the building sector. Each country however is free on the exact way how to do so as long as its specific approach is in line with the general EU roadmap. This paper assesses the effect of the implemented frameworks for France and Germany and draws conclusions regarding immediate and future phenomenon. Findings are that both countries have implemented holistic frameworks that include legal standards, financial incentives and market education. While the German setup focusses on systemic solutions though, France promotes a component based subsidy scheme. In both countries the refurbishment rate on a component level is substantially higher than for deep renovation with window exchange and roof refurbishment being the most commonly implemented ones. Component based measures are higher in France than in Germany, in some cases even meeting the aimed for $3 \%$ needed for a refurbishment of the complete building stock by 2050 on an EU level. In general however both countries fail to achieve refurbishment and renovation rates that enable them to stand up to the EU 2050 targets yet, indicating that the market barrier and mechanisms have to be monitored and understood better to implement massive upscaling of energy efficient technologies.
\end{abstract}


Keywords: Innovation barrier, refurbishment, building technologies, upscaling, market diffusion.

\section{Introduction}

The 5th IPCC report [2] identifies the built environment to be responsible for $32 \%$ of global final energy use and $19 \%$ of all greenhouse gas (GHG) emissions. In absolute numbers this means that $6,865 \mathrm{Mt}$ of $\mathrm{CO}_{2}$ eq anthropogenic emissions are resulting from buildings [3], a number that under business as usual scenarios can double or even triple by 2050 .

From these global emissions, 6,4\% are embodied emissions and 25,6\% are emissions during the usage phase due to heating, cooling, warm water and domestic electricity usage. The IPCC also lists a substantial emission reduction potential of $50-90 \%$ in existing and new buildings mainly due to improvements in the envelopes and energy efficient housing services/ HVAC making them a key sector to be addressed in order to limit Climate Change [2].

In the EU, buildings are responsible for $40 \%$ of energy consumption and $36 \%$ of $\mathrm{CO}_{2}$ eq emissions [4]. Compared to global numbers this indicates the higher efficiency of other sectors and the outsourcing of less efficient sectors out of the EU system boundary. It also explains the central role of the built environment in the EU strategy to mitigate its emissions. This focus is complemented with a number of possible side benefits of more energy efficient such as higher comfort and health issues.

In order to contribute to the mitigation of climate change, the EU has committed itself to ambitious carbon reduction targets in the building sector. EU leaders agreed on $23^{\text {rd }}$ of October 2014 at the European Council Summit on the domestic 2030 greenhouse gas reduction target of at least $40 \%$ compared to 1990 together with other main building blocks of the 2030 policy framework for climate and energy, as proposed by the European Commission in January 2014. The 2030 policy framework aims to make the European Union's economy and energy system more competitive, secure and sustainable and also sets a target of at least $27 \%$ for renewable energy and energy savings by 2030 [5].

The main legislation in order to ensure the reduction of energy consumption in buildings related to these targets are the 2010 Energy Performance of Buildings Directive (EPBD) and the 2012 Energy Efficiency Directive (EED) [5]. The main pillars of this legal framework are:

- Energy performance certificates are to be included in all advertisements for the sale or rental of buildings

- EU countries must establish inspection schemes for heating and air conditioning systems or put in place measures with equivalent effect

- All new buildings must be nearly zero energy buildings by 31 December 2020 (public buildings by 31 December 2018)

- EU countries must set minimum energy performance requirements for new buildings, for the major renovation of buildings and for the replacement or retrofit of building elements (heating and cooling systems, roofs, walls, etc.) 
Whereas the main legislation comes from an EU scale, each country has to draw up lists of national financial measures to improve the energy efficiency of buildings [4].

In the current European building stock, it is estimated that there is 25 billion $\mathrm{m}^{2}$ of useful floor space in the EU27, Switzerland and Norway of which $35 \%$ of the EU's buildings are over 50 years old (Figure 1). This often results in the need for maintenance work and repairs that can be combined with an energetic refurbishment, in order to reach the minimum level of energy efficiency required.

While new buildings generally need less than three to five liters of heating oil per square meter or 6 $-10 \mathrm{kgCO} 2 \mathrm{eq} / \mathrm{m}^{2}$ per year, older buildings consume about 25 liters or $50 \mathrm{kgCO} 2 \mathrm{eq} / \mathrm{m}^{2}$ on average. Some buildings even require up to 60 liters or $120 \mathrm{kgCO} 2 \mathrm{eq} / \mathrm{m}^{2}$ liters. $5 \%$ [4].

Figure 1. Age categorization of housing stock in Europe [6].

South

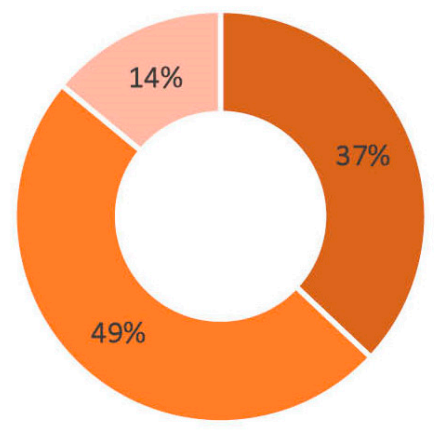

- Pre 1960 - 1961-1990 - 1991-2010
Central \& East
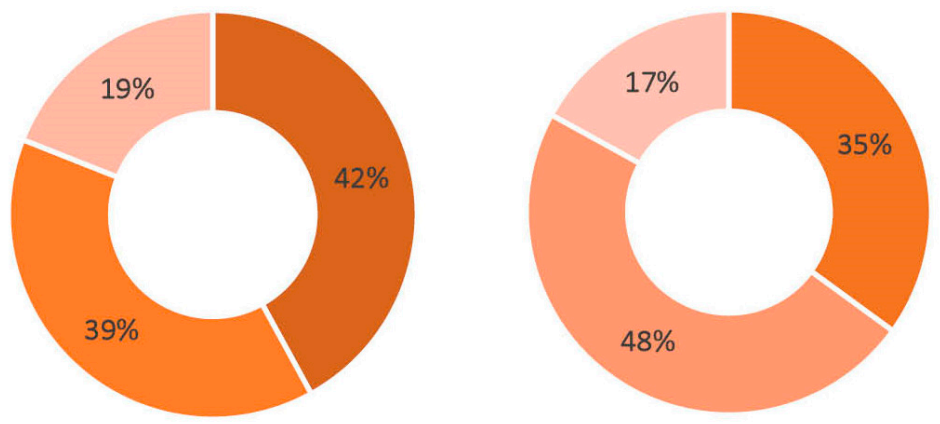

Within the building stock about $75 \%$ of all buildings are residential, among this group $64 \%$ are single family homes.

While the requirement for the energy performance in major refurbishment is only one of the pillars in effect it is the most relevant in terms of achieving the EU 2030 targets. Within this pillar the sector that is of the highest relevance is the fractured sector of individual residential homes.

Given the current EU building stock, in order to achieve EU's target for 2050, the ambition is to see all EU buildings renovated between now and 2050. This means $100 \%$ renovation within 40 years or an average renovation rate of $2.5 \%$ p.a. Current refurbishment rates in the EU are estimated by the BPIE at $1 \%$ and a decrease in the rate of new build in the recent years, accordingly levels of activity need to more than double to achieve the required annual rate [4] Under the Energy Efficiency Directive the EU countries should make energy efficient renovations to at least 3\% of buildings owned and occupied by central government as well as they must draw-up long-term national building renovation strategies which can be included in their National Energy Efficiency Action Plans.

The EU requires all members to come up with financial measures to support their National Energy Efficiency Action Plans. In line with this national governmental schemes come in the form of building codes and standards and financial incentives or subsidy schemes, mostly focusing on lower interest rates for loans for energy efficient buildings and refurbishment. 
Despite the current focus of global and European governmental bodies on financial incentives and policy frameworks, other institutions such as the WBCSD, IPCC, BPIE or UNEP have pointed out the more complex nature of the situation, including barriers such as lack of knowledge and trust, institutional and administrative, awareness or lack of communications, amongst others.

This complexity of the situation versus the financial barrier is reflected by abatement calculations such as the cost-abatement curves from McKinsey [5] and European projects like Entraze [6]. These sources clearly show the economic potential of low-carbon technologies in the building sector, several of them being at abatement costs of -50 US-Dollars/ton carbon and less. Even under this very favorable economic condition these technologies are not being implemented at the required rate.

In order to achieve the ambitious goal of more than doubling refurbishment rate and implementing refurbishment standards that go beyond the current state of play the barriers need to be identified and understood and addressed by tailored frameworks to overcome them.

This paper tries to assess the effect of the existing economic incentives and policy frameworks as a first step to generate a quantified understanding of market barriers and their effects. Because of the complexity of the issue and the interchange of different aspects the direct impact of individual barriers is challenging to assess. This project tries to do so on a case study basis by analyzing existing data sources and then aims to generalize/categorize the findings.

This paper assesses the impact of policy and economic incentives by combining data on diverse indicators that describe the refurbishment sector with the most important laws issued over the last 15 years for two countries, France and Germany.

One major concern is that the use of financial instruments today is only achieving the business-asusual case in Europe with very few financial instruments providing enough funding for deep renovations. If the goal is to significantly increase the number of deep renovations to meet 2050 aspirations, it will require to exceed the current policy and economic measure, with sharpened or more innovative approaches which can ensure a market transformation [4].

\section{Method}

In this paper publically available data from two different countries (Germany and France) was collected from statistical offices and other governmental bodies. These countries where identified as having the most extensive data available, however the collected data still differs greatly between the countries. Therefore, a comparable assessment of the effect of the different policy measures between the countries is still not possible. However, from the collected data different indicators for the renovation and refurbishment activities in this country could be derived. The indicators are described in the following section. The data sources for each of the countries and each indicator are listed in Table 1.

\subsection{Indicators}

\subsubsection{Refurbishment rate}

The actual refurbishment rate, preferably on a building component level, is of course the ideal indicator, however, it is not measured on a complete building stock level for any country in the level of detail needed. Both France and Germany conducted surveys, which quantified a refurbishment rate on a 
component level. In the case of France the survey is even conducted on an annual basis, however, missing information on the extent (complete or only partial refurbishment) of the refurbishment measures conducted [7-11]. The survey conducted in Germany accounts for partial refurbishment in the estimate of the refurbishment rate, it was however, conducted only once in 2010, yielding only average refurbishment rates for a certain period instead of annual data [12].

\subsubsection{Renovation rate}

The renovation rate is based on the number of building permits issued for renovation work per building or dwelling in the national building stock. While this indicator does not cover all refurbishments as for example the exchange of windows can be carried out without a building permit, it is however indicative of the rate of major refurbishments covering several components. As Table 1 shows the necessary data is, however, only available for Germany.

\subsubsection{Investment in Renovation}

The indicator "Investment in Renovation" describes the investment in renovation work divided by the number of building permits issued. Coupled to the renovation rate, this should give an indication on the extent of the renovation. The data necessary is however only available for Germany.

\subsubsection{New construction rate}

The indicator "new construction rate" is based on the number of buildings/dwellings added to the stock per building/dwelling in the national building stock. It functions as a reference indicator for the development of the rest of the construction activity apart from to renovation and refurbishment.

\subsubsection{Investment in new Construction}

Similar to the indicator "Investment in Renovation", the indicator "Investment in new Construction" describes the investment in new buildings divided by the number of buildings/dwellings added to the stock. Coupled to the renovation rate, this should give an indication on the extent of the renovation.

\subsubsection{Energy standards}

The Energy Standard lists the minimum energy efficiency, defined as energy demand per useful floor area, in the respective country. As the two countries that are compared in this study are using different units for the calculation of the energy demand of their buildings and also define the useful floor area differently this indicator is indexed with the 2001 standard being set to 1 .

\subsubsection{Number of energy audits per year}

The Indicator list the number of energy efficiency related audits conducted by licensed experts in the respective year. This indicator is indexed with the 2001 standard being set to 1 .

\subsubsection{Energy price}


The Indicator lists the price for heating oil. This indicator is normalized based on the costs of one hectoliter and indexed with the 2001 standard being set to 1 .

\subsubsection{Interest rate}

The Indicator lists the interest rates on new 1 to 5 years nonfinancial loans in the respective country. The data is indexed with the 2001 years values set to 1 .

Table 1. Data sources of the different indicators for the three countries.

\begin{tabular}{|c|c|c|}
\hline Indicator & Germany & France \\
\hline Refurbishment rate & $\begin{array}{l}\text { Average component-based values } \\
\text { based on survey data from } \\
\text { Diefenbach et al. [14] }\end{array}$ & $\begin{array}{l}\text { Annual component-based values based } \\
\text { on survey data from TNS Sofres [9-12] }\end{array}$ \\
\hline Renovation rate & Based on Data from GFOS [14] & Not-available \\
\hline $\begin{array}{l}\text { Investment in } \\
\text { Renovation }\end{array}$ & Based on Data from GFOS [14] & Not-available \\
\hline New construction rate & Based on Data from GFOS [14] & Based on Data from CEREN [15] \\
\hline $\begin{array}{l}\text { Investment in new } \\
\text { Construction }\end{array}$ & Based on Data from GFOS [14] & $\begin{array}{l}\text { Based on Data from CEREN and } \\
\text { INSEE [14-15] }\end{array}$ \\
\hline Energy Standard & Based on Data from IEEA [17] & Based on Data from MEDDE [18] \\
\hline $\begin{array}{l}\text { Number of energy } \\
\text { audits }\end{array}$ & Based on BAFA [19] & Not-available \\
\hline Energy price & Based on Data from GFOS [20] & Based on Data from INSEE [21] \\
\hline Interest rate & Based on Data from ECB [22] & Based on Data from ECB [22] \\
\hline
\end{tabular}

\section{Results and Discussion}

A comparative assessment of refurbishment activities of different countries is hindered by the lack of data reporting the refurbishment rates in different countries as well as the differences in the data reported. On a European scale, comparable and consistent data on the development of refurbishment activities does not exist. Mayor reports such as the one from BPIE [4] only refer to the generally agreed upon level of the refurbishment rate of around $1 \%$, which is however lacking a solid data basis. Moreover, on a component level, the refurbishment rate can diverge significantly from this $1 \%$ as shown by reports such as [9-13]. These reports show that especially windows are refurbished at a much faster rate.

The general lack of data available is amplified by the fact, that each country collects buildings stock data differently. The data available from national statistics, therefore, differs greatly in both the level of detail and the extent of the data, making a comparable assessment even more difficult.

\subsection{Germany}

The Federal Government has opted for a differentiated strategy in regard to measures enhancing energy efficiency to achieve the EU's targets. In the building sector, the approach focuses on 'Require, 
support, inform - strengthen market forces'. 'Require' by regulatory law; 'Support' by means of financial incentives and 'Inform' by increasing transparency in the market.

The regulatory law consists of two main laws; the Energy Conservation Regulation (EnEV) [21] and the Renewable Energies Heat Act (EEWärmeG) [22], mainly for new buildings. The Energy Conservation Regulation (EnEV) regulates the energy demand calculation methods and minimum standards for new buildings and refurbishments. In order to meet energy efficiency targets of 2020, the minimum standards are increased every few years.

The key instruments in regard to 'Support' are the Kreditanstalt für Wiederaufbau (KfW) support programmes for energy-efficient construction and refurbishment $\left(\mathrm{CO}_{2}\right.$ building refurbishment programme), the KfW programme 'Energetic urban renewal' as well as the market incentive programme for the promotion of systems for the use of renewable energies. Through local banks, the KfW body hands out subsidies on the form of decreased interest rates for building loans whose amount depends on the efficiency of the building in question. The different thresholds are defined as percentages of the minimum energy efficiency standards. The higher the efficiency level of the refurbishment is, the higher the percentage of the subsidy is [23]. Germany therefore focuses on a systemic improvement of the energy efficiency of the building, rather than an individual improvement of specific components. Private individual investors also have the option to receive a direct grant rather than decreased interest rates.

The federal government is acting to 'Inform' and strength market forces at several levels. Firstly, standards for the quality of training of energy consultants as well as for the energy standards of buildings are developed and codified. Second, the federal government has been working in the field of research. Energetically demanding standards and modern technologies are tested and implemented. Ultimately it is involved through the existing counseling and support programs also in the implementation of energy consultancy [24]. EPDs for buildings are to be provided by the owner of the building on request every time the owner or tenant changes. They can come either in the form of demand based (calculated) or consumption (measured) based certificates for buildings built after 1978. For buildings older than 1978 a demand based certificate is mandatory to allow the easy generation of refurbishment options, Figure 3 and 4 show the generated Indicators for Germany.

The renovation rate in Germany remains at a relatively low level from 2000 to 2013 . While the investment per renovation tends to increase, the renovation rates trend is towards $0,2 \% / \mathrm{a}$. This is only a fifth of what it is generally assumed to be in the BPIE data. However, the average component based refurbishment rates indicate that on a component level, the refurbishment rate is higher. Suggesting that refurbishments are still conducted a component at a time and not as a major refurbishment. The increased costs per renovation can be explained by the increased energy efficiency levels that have to be met according to ever stricter standards. Growing expertise on the market in energy efficient buildings does not seem to compensate this as the conducted investment per new building is also increasing. Another possible explanation for decreasing renovation rates could be Germanys relatively long history of refurbishment with the most easy to refurbish building already having been dealt with and only buildings which are more complicated from a construction viewpoint being left over.

Germany can demonstrate a successful campaign of market education via an extensive number of energy efficiency audits however this does not result in an uptake of renovation. It might be an explanation though for the increased amount of financial incentives used for energy efficiency measures as the energy efficiency audits also include information on available subsidy schemes. 
Rising energy prices as well as favorable interest rates in combination with the established subsidy scheme via the KfW result in relatively favorable economic frame condition compared to other EU countries. Low interest rates might yet be another explanation for increased investment costs while increasing energy prices, often being used as key argument in favor of energetic refurbishment, seem at least not to be on a level yet to trigger large scale renovation initiatives.

Figure 3. Indicators for the case of Germany based on data sources listed in Table 1.
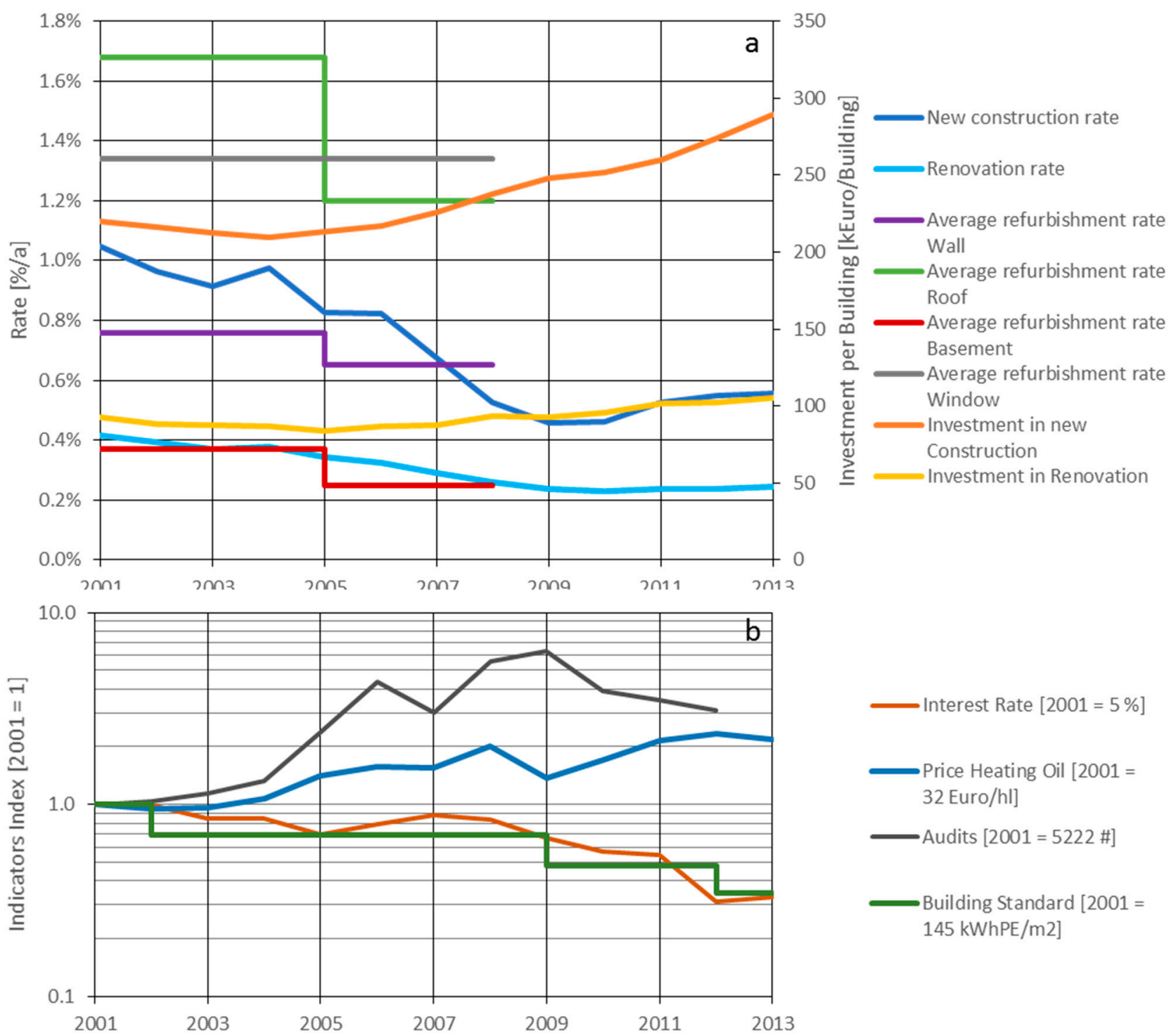

\subsection{France}

In France the activity of the building sector, whether it entails the construction of new buildings or the renovation of existing stock, is primarily governed by the planning act for the implementation of the decisions taken at the Grenelle Round Table on the Environment (Statute No 2009-697 of 3 August 2009, commonly known as the First Grenelle Act). The Grenelle process has established a set of tools for the reduction of energy consumption in both new and existing buildings. The National Environmental Commitment Act (Statute No 2010-788 of 12 July 2010, commonly known as the Second Grenelle Act), complements the planning act and provides that toolkit for the fulfilment of the Grenelle commitments. 
Measures designed to ensure that all existing buildings become low-consumption buildings to meet EU's targets are: regulations, the energy performance certificate (EPC) and financial mechanisms.

The Thermal Regulations for existing buildings apply to existing residential and public-service buildings when the contracting authority for such buildings makes arrangements for renovation works.

The overarching aim of the Regulations is to ensure that the energy performance of an existing building is significantly improved whenever a client undertakes operations with the potential to bring about such an improvement. For other renovation works, only equipment with high energy performance may be used, and this rule impacts directly on the market in compliant equipment. In alignment with the EU roadmap the energy efficiency standards are becoming stricter in several steps, with near-zero energy levels for new buildings from 2020.

Several financial mechanisms for the renovation of existing buildings one can find are implemented in France Interest-free eco-loans (Eco-PTZ) that are intended for individual owner-occupiers or landlords to finance major renovation works, a sustainable-development tax credit which is a fiscal mechanism enabling individuals to deduct from their income-tax liability part of their expenditure on particular improvement work designed to improve the energy performance of their main residence. In addition the governmental bank offers Energy Savings Credits, based on an obligation imposed by the public authorities on energy providers - sellers of electricity, gas, heat, refrigeration and domestic heating oil - to make energy savings with three-year savings target is defined and is distributed among the operators on the basis of their sales volumes.

Some especially relevant sectors like the social housing stock are targeted with specific formats. EcoLoans for social housing and site-ratio bonus for example is a scheme introduced by the Grenelle environmental package for the rehabilitation of the social-housing stock with the highest levels of energy consumption.

France has an established system of energy audits that are conducted by certified energy experts and that are subsidized by central funds for the promotion of energy efficiency, as regulated in Article L. 111-9 of the Building and Housing Code introduced by the Law of 13 July 2005 and Article 1 of Grenelle 2. The Energy Performance Certificate (EPC) provides information on the energy performance of a dwelling or building by assessing its energy consumption and its environmental impact in terms of greenhouse-gas emissions.

Since the start of 2012, the owners of all parts of a building have been under an obligation to obtain an EPC for their property if the building is equipped with a common boiler for heating purposes; this requirement serves to make larger numbers of people aware of the issue of energy saving and the associated financial mechanisms.

For France, no deep refurbishment rate is available, however investment in new buildings and new building rate allow for a comparison of the general situation of the building sector with Germany The new construction rate in France is nearly double that of Germany while investments are substantially lower. This is to be attributed to work costs as the energy efficiency standards do not differ to an extreme extent. Both countries economic frame conditions are characterized by increasing energy prices and decreasing interest rates for building loans.

For refurbishment rates the available data is generated on a component based level, based on an annual survey of 10.000 households that allows for a high level of resolution while being reasonably statistically valid. Technologies which imply least disturbing implementation effects to the occupant, have a higher 
efficiency effect or add useful floor area are in some cases scaling up at a rate higher than the EU's announced 3\% threshold to have the complete building stock refurbished by 2050 . This is mainly the case for single glazing or roofs. Other technologies such as refurbishment of walls or floors, are shown to scale at slower speeds. In all cases the France setup of a subsidy scheme focused on component bases refurbishment results in all cases in higher rates for such measures than in Germany.

Figure 4. Indicators and policy measures for the case of France based on data sources listed in Table 1.

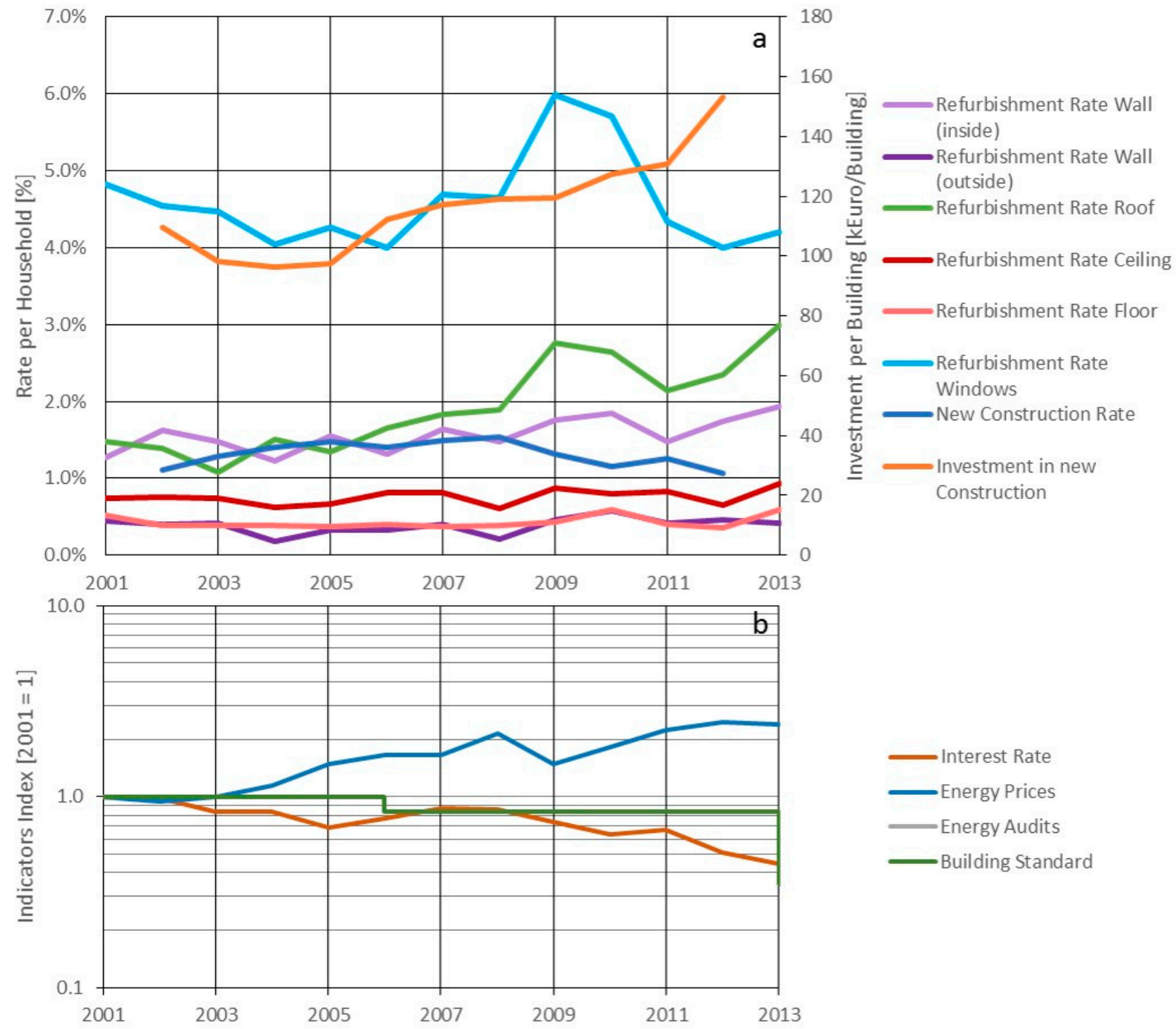

Compared to the Germany's assessment, French data is not corrected to partial measures. This means that partial measures might as well account in the final values of these indicators.

As there is no available data for the number of audits performed. It is not possible to compare the effect of this measure with the indicators, however a working energy efficiency audit format is in place and a decent market information level can be assumed. 


\section{Conclusions}

While both assessed countries have implemented the Energy Efficiency directive of the EU and try to promote major renovation neither of them is on its way towards the necessary $3 \%$ / a to achieve the 2050 Targets. Both countries implemented similar policy measures such as energy efficiency audits, increasing energy efficiency standards and the use financial incentives such as a decreased interest rate and grants for energy efficiency measures. They have, however, different approaches in setting up the requirements for subsidies. The German approach focuses more on systemic improvements of the energy efficiency of the whole building, while France focuses more on the individual component. However, in both cases individual components are refurbished at a higher rate than major renovations. The stronger component focused approach from France seems to be resulting in higher component-based refurbishment rates. For an individual upscaling of certain technologies the French approach seems to be favorable, however, it is likely to cause sub-optimal overall concepts on the long run as partially refurbished buildings are less likely to adopt further measures.

The lack of aligned data makes the comparison between the two countries difficult and limits the conclusion that can be drawn. Even if France and Germany were mainly chosen due to the comparably good data availability. An assessment on a pan-EU level and comparison of all Member-States would therefore be even more challenging if not impossible. This prevents a complete comparison of different country's strategies. Therefore, aligned pan-EU data is needed for the development of a sound EU strategy.

The renovation rate of the two countries show that the market needs to be activated far beyond what is currently happening in order to reach the 2050 targets - with incentives to address the commonly named key barriers in place there seem to be other mechanisms and barriers that keep change from happening. Therefore, there is a need for quantification of barriers and a focus on market mechanism especially the increasing cost per renovation and new buildings are an indication that the assumed cost reduction due to optimization is not happing to the expected extend.

\section{Acknowledgments}

This work is part of the project Building Market Applied Barrier Categorization funded by the Knowledge and Innovation Community on Climate (Climate-KIC), supported by the European Institute for Technology (EIT) a body of the European Union. The authors would like to express their gratitude towards these bodies for funding the research.

\section{Conflict of Interest}

The authors declare no conflict of interest.

\section{References and Notes}

1. McKinsey and Company; 2010: Pathways to a low-carbon economy: Version 2 of the global greenhouse gas abatement cost curve

2. Field, C.B.; V.R. Barros; D.J. Dokken; K.J. Mach; M.D. Mastrandrea; T.E. Bilir; M. Chatterjee; K.L. Ebi; Y.O. Estrada; R.C. Genova; B. Girma; E.S. Kissel; A.N. Levy; S. MacCracken; P.R. 
Mastrandrea; and L.L. White. Climate Change 2014: Impacts, Adaptation, and Vulnerability. Summary for policymakers. Part A: Global and Sectoral Aspects. Contribution of Working Group II to the Fifth Assessment Report of the Intergovernmental Panel on Climate Change. IPCC, 2014, 132.

3. GCP. Global Carbon Atlas. Available at http://www.globalcarbonatlas.org/?q=en/emissions [Accessed at 05.04.2015]

4. EU. European Commission. Available at http://ec.europa.eu/energy/en/topics/energyefficiency/buildings [Accessed at 09.04.2015]

5. EU. European Commission. Available at http://ec.europa.eu/clima/policies/2030/index_en.htm [Accessed at 09.04.2015]

6. Economidou, M.; Atanasiu B.; Despret C.; Maio J.; Nolte I.; Rapf O. 2011. Europe's buildings under the microscope. BPIE, Building Performance Institute Europe. Brussels, Belgium, 2011

7. Impact of the financial crisis on carbon economics. Version 2.1 of the Global Greenhouse Gas Abatement Cost Curves. McKinsey. 2010

8. Kranzl, L., Toleikyte A., Müller M., Humme M., Heiskanen E., Matschoss K. Laying Down the Pathways to nearly Zero-Energy Buildings. A toolkit for policy makers, ENTRANZE, 2014

9. TNS Sofres. Baromètre 10000 ménages : Maîtrise de l'énergie - Bilan 2004 - 2ème Phase, ADEME, Valbonne, France, 2005.

10. TNS Sofres, Baromètre 10000 ménages : Maîtrise de l'énergie - Bilan 2007 - 2ème Phase, ADEME, Valbonne, France, 2008.

11. TNS Sofres. Baromètre 10000 ménages : Maîtrise de l'énergie - Bilan 2010 - 2ème Phase, ADEME, Valbonne, France, 2011.

12. TNS Sofres. Baromètre 10000 ménages : Maîtrise de l'énergie - Bilan 2013 - 2ème Phase, ADEME, Valbonne, France, 2014.

13. Diefenbach, N. et al. Datenbasis Gebäudebestand - Datenerhebung zur energetischen Qualität und zu den Modernisierungstrends im deutschen Wohngebäudebestand, Darmstadt, Germany, 2010.

14. GFSO. Buildings and Housing Statistics. German Statistical Office. Available at https://wwwgenesis.destatis.de/genesis/online;jsessionid=ED1552D4F325EA995A79C200F3B74E88.tomcat_

GO_1_2?operation $=$ previous\&levelindex $=0 \&$ levelid $=1430927884323 \&$ step $=0 \quad[$ Accessed at 26.03.2015]

15. CEREN. Données statistiques du CEREN, Paris, France, 2014.

16. INSEE. Investissement en construction en 2013. Available at http://www.insee.fr/fr/themes/tableau.asp?reg_id=0\&id=235 [Accessed at 26.03.2015]

17. IEEA, 2014. EnEV-Archiv. Energieeinsparverordnung für Gebäude. Available at http://www.enevonline.de/enev/ [Accessed at 07.05.2015]

18. MEDDE. Réglementation thermique: un saut énergétique pour les bâtiments neufs. Ministère de l'Écologie, du Développement durable, des Transports et du Logement. 2012

19. BAFA. Evaluation der Energiesparberatung vor Ort Endbericht, Exchborn. Bundesamt für Wirtschaft und Ausfuhrkontrolle (BAFA). Germany, 2014.

20. GFSO. Daten zur Energiepreisentwicklung - Lange Reihen. Available at https://www.destatis.de/DE/Publikationen/Thematisch/Preise/Energiepreise/Energiepreisentwicklu ng.html [Accessed at 01.05.2015] 
21. INSEE. Monthly average consumer prices in metropolitan France. Available at http://www.insee.fr/en/bases-de-donnees/bsweb/serie.asp?idbank=000442573 [Accessed at 07.05.2015]

22. ECB. Statistical Warehouse of the European Central Bank - Long-term interest rates. Available at http://sdw.ecb.europa.eu/browse.do?node=bbn4864 [Accessed at 07.05.2015]

23. IEA. International Energy Agency. Energy Saving Ordinance (residential buildings). Available at http://www.iea.org/policiesandmeasures/pams/germany/name-34988-en.php [Accessed at 20.04.2015]

24. IEA. International Energy Agency. Energy Saving Ordinance (residential buildings). Available at http://www.iea.org/policiesandmeasures/pams/germany/name-34988-en.php [Accessed at 20.04.2015]

25. IEA. International Energy Agency. Energy Saving Ordinance (residential buildings). Available at http://www.iea.org/policiesandmeasures/pams/germany/name-24388-en.php [Accessed at 20.04.2015]

26. Pehnt, M.; Lambrecht, K. Der Sanierungsfahrplan BW. IFEU, ECONSULT, ECONSULT Lambrecht Jungmann Partner und Institut für Energie- und Umweltforschung Heidelberg GmbH. 2014

27. Schüle, R.; Bierwirth; A., Madry T. Zukunft der Energieberatung in Deutschland. Wuppertal Institut für Klima, Umwelt, Energie. 2011

(C) 2015 by the authors; licensee MDPI and IFoU, This article is an open access article distributed under the terms and conditions of the Creative Commons Attribution license. 